\title{
Analysis of 9,896 Homeless Patients within an Urban Area in 2014 - 2019 - Social Pathology Leading to Poor Health
}

C. Prochazkova (Catherine Prochazkova)', E. Grey (Eva Grey)1,2, G. Mikolasova (Gertie Mikolasova)1,2, L. Libova (Lubica Libova)1,2, I. Hupkova (Inge Hupkova)1,2, K. Pauerova (Kristina Pauerova), 1,2 R. Hochamn (Rastislav Hochman),2, M. Jancovic (Mario Jancovic)1,2, B. Hofbauer (Blanka Hofbauer)1,2, M. Sramkova (Maria Sramkova) 1,2, P. Stankova (Petra Stankova)1,2, M. Bosnakova (Monika Bosnakova)², A. Murgova (Anna Murgova)1,2, M. Katunska (Monika Katunska)', P. Tomanek (Pavol Tomanek)1,2, M. Mikloskova (Monika Mikloskova)1,2, J. Miklosko (Jozef Miklosko), 1,2, R. Vlcek (Robert Vlcek) 1,2, M. Palenikova (Milica Palenikova)1,2, J. Drgova (Jaroslava Drgova)1,2, R. Kovac (Robert Kovac), ${ }^{1,2}$, D. Kimuli (Daria Kimuli)3, D. Kalatova (Dagmar Kalatova)', V. Kozon (Vlastimil Kozon) ${ }^{1,4}$, H. Konosova (Helena Konosova)', M. Popovicova (Maria Popovicova)' , T. Hrindova (Tatiana Hrindova)' ${ }^{1}$ J. Otrubova (Jana Otrubova) ${ }^{1}$

1 St. Lesley College and St. John Neumann Institute SEUC Nove Zamky

Original Article and Pribram, Czech Republic.

2 Mea Culpa St. Luise de Marillac, Resoty and St. Elizabeth Shelters for Homeless, P.F. Freiberg Institute of PP Psychology, Bratislava, Slovakia.

3 St. Philippe Nori Centre Nairobi, Kenya.

${ }^{4}$ Allgemeines Krankenhaus (AKH) Med. University Teaching Hospital Vienna, Austria.

\section{E-mail address:}

jana.otrubova@gmail.com

\section{Reprint address:}

Jana Otrubova

St. Lesley College

Nove Zamky

Slovakia

Source: Clinical Social Work and Health Intervention Pages:

Volume: $10 \quad$ Issue: 4 Cited references: 3

\section{Reviewers:}

Andrea Shahum

University of North Carolina at Chapel Hill School of Medicine, USA

Viktor Namulanda

Mukuru, Kenya 


\section{Keywords:}

Homeless. Health care.

\section{Publisher:}

International Society of Applied Preventive Medicine i-gap

CSWHI 2019; 10(4): 67 - 69; DOI: 10.22359/cswhi_10_4_09 @ 2019 Clinical Social Work and Health Intervention

\section{Abstract:}

Introduction: Homeless populations in EU and USA presents an increasing demographic. Social pathology includes substance or alcohol abuse, family and unemployment distress, and several other factors resulting to poverty and homelessness.

Patients and Methods: The purpose of this study was to analyze the spectrum of both communicable and non-communicable diseases in two different urban environments: Large metropolitan area (BA) versus small regional town (NZ); one with 500,000 and other with 50,000 population.

Results: Between January 2014 to December 2019, 9,896 homeless patients in Bratislava and 299 in Nove Zamky were analyzed for the spectrum of communicable and non-communicable disieases. Commonest ID had seasonal occurrence; respiratory tract infections (RTI) in November to March, and gastrointestinal from June to September.

Conclusion: Vaccination of all homeless should be considered to prevent RTI TB, HIV, HCV in shelters

\section{Introduction:}

Large inequities in Europe and SE Asia as well as in Latin America resulted from at least two emergencies in social pathology: internal (homelessness) and external (migrant and refugee crisis). Homeless populations in the EU and the USA presents an increasing demographic. Social pathology includes substance or alcohol abuse, family and unemployment distress, and several other factors resulting in poverty and homelessness. Special concerns are in tuberculosis (TBC) and Hepatitis B, C and AIDS (1-3). The aim of this research is to assess the occurrence of patients at two outpatient departments of Homeless Health Posts in a large urban versus local urban setting, capital versus district cities.

\section{Patients \& Methods}

Several health posts and one hospital serve the homeless population in Bratislava and Nove Zamky. The purpose of this study was to analyze the spectrum of both communicable and non-communicable diseases in two different urban environments: large metropolitan area (BA) versus small regional town (NZ); one with 500,000, the other with 50,000 population.

\section{Results \& Discussion}

Table 1 shows increasing dynamics of the total number of patients among the homeless population among 9,986 patients in 6 years in Bratislava and 299 in Nove Zamky. Respiratory tract infections were 
responsible for more than $50 \%$ of all visits (511\& $150-50.2$ vs $50.1 \%)$.

\section{Conclusion}

Vaccination of all homeless should be considered to prevent hepatitis, TBC and influenza, and PH control for shelters is essential. Staff should be prevented from burnout syndrome (2). Suprisingly, no case of TB apart of 1 case was noted in $2014-2019$.

\section{Table 1. Annual occurence of CD/NCD}

\begin{tabular}{|r|r|r|r|r|r|r|}
\hline 2014 & 2015 & 2016 & 2017 & 2018 & 2019 & Total \\
\hline 1,387 & 1,411 & 1,635 & 1,711 & 1,831 & 1,911 & 9,986 \\
\hline
\end{tabular}

\section{References:}

1. BELOVICOVA M, MURGOVA A, VANSAC P, POPOVICOVA M, BALAZOVA I, NEMCIKOVA M, MASTEROVA V, URBANOVA A, FABISKOVA K, BALAZIOVA A (2019) Hepatitis C Screening in Selected social reintegration facilities in Eastern Slovakia. Clinical Social Work and Health Intervention, 10, 2, p. 25-31. ISSN 2222-386X.

2. ZACHAROVA E, KOZON V (2019) Factors Influencing The Fluctuations of Nursing Staff. Clinical Social Work and Health Intervention, 10, 2, p. 110-118. ISSN 2222386X.

3. PERI HAJ ALI, SUBRAMANIAN S, SLADECKOVA V, BYDZOVSKY J, DURCOVA B, OLAH M, MATULNIKOVA L, KUBIK F, DOKTOROV V, BERESOVA A, FULA M (2019) Early detection of advance therapy reactions in orphans with AIDS. Acta Missiologica Vol.13, No 2, p. 184. 